\title{
技術ノート
}

\section{佐賀県における豆腐粕，大麦焼酎粕および 秋芽茶を活用した豚肉生産技術}

\author{
脇屋裕一郎・大曲秀明・安田みどり*・宮崎秀雄 ${ }^{* *}$ ・ \\ 明石真幸**・河原弘文・下平秀丸 \\ 佐賀県畜産試験場，武雄市，849-2305 \\ * 学校法人永原学園西九州大学健康栄養学科, 神埼市, 842-0015 \\ **佐賀県茶業試験場，嬉野市， 843-0302
}

(2010 年 5 月 6 日受付, 2010 年 9 月 13 日受理)

\section{緒言}

とうあろこしのバイオマス利用等の影響による 飼料価格の高騰が養豚農家経営存続にとって大き な不安要因となっており, その対策として食品の 製造および流通過程で排出される食品廃棄物など の地域未利用資源の飼料利用が求められている。

また, 循環型社会を構築する観点から, 平成 13 年に「食品循環資源の再生利用等の促進に関する 法律 (食品リサイクル法)」が施行され, 食品廃棄 物のリサイクルを進めるべき法的義務が生じたこ とで, 事業者サイドにおいても広範囲に利用でき る手段として，飼料化に重点が移ってきている。

しかし, 地域未利用資源は水分含量が高く保存 性等の課題等があるものも少なくなく, また，栄 養成分が安定しないことより, 豚肉の軟脂や背脂 肪厚の増加等による格付の低下が懸念されるため
(入江 2002), 利活用が敬遠されているのが現状で あり, 日本に扒いて食品廃棄物は年間約 1,135 万 $\mathrm{t}$ 発生されるが，そのうち飼料に向けられている のは約 136 万 $\mathrm{t}(12 \%)$ と伸び悩んでいることが 報告されている（農林水産省大臣官房統計情報部 2008)。

また, 畜産物の生産において, 輸入量の増加や 国内での産地間競争が激化する中で, 地域の特徵 を活かした生産技術の確立が望まれており，それ ぞれの地域の特産品の副産物を飼料利用した地域 性豊かで機能性の高い畜産物生産の取り組みが実 施されているため (小平ら 2007 ; 石田ら 2007 ; 堀 之内ら 2008), 地域での発生量と安定した供給量 等を考慮して高品質畜産物を生産できる地域未利 用資源を選定する必要がある。

佐賀県内に扔いて安定した供給が可能な資源と して豆腐粕および大麦焼酎粕があげられるが，特

Pig Production Utilized Soybean Curd Residue, Shochu Distiller's Residue (Barley) and Autumn Bud Tea in Saga Prefecture

Yuichiro Wakiya, Hideaki Omagari, Midori Yasuda*, Hideo Miyazaki**, Sadayuki Akaishi**, Hirofumi KaWAHARA and Hidemaru SHIMOHIRA

Saga Prefectural Livestock Experiment Station, Takeo-shi 849-2305, Japan

* Department of Health and Nuturition Science, Nishikyushu University, Nishikyushu University, Kanzaki-shi 842-0015, Japan

** Saga Tea Experiment Station, Ureshino-shi 843-0302, Japan

連絡者: 脇屋裕一郎（E-mail：wakiya-yuuichirou@pref.saga.lg.jp Tel. 0954-45-2030) 
に大麦焼酎粕は，水分含量が高く単独での乾燥処 理が困難であるため, 水分含量が低い市販飼料等 と混合して水分調整することで効率的な乾燥処理 が可能となることが考えられる。

また, 佐賀県畜産試験場では, 県内特産物であ る茶の製茶工程で発生する製茶残さを利用した高 品質豚肉生産技術の開発を行い, 市販飼料に茶葉 を添加することで豚肉の背脂肪厚低減効果等を確 認しており（坂井ら 2007 ; 脇屋ら 2009）, 茶を利 用することにより，豆腐粕の多給により懸念され る厚脂や軟脂を抑制できることが考えられる。

そこで, 本試験では, 佐賀県内で発生する地域 未利用資源である豆腐粕, 大麦焼酎粕および秋芽 茶を市販飼料と混合して乾燥処理を行った飼料の 成分分析を行うとともに, 肥育豚への給与試験を 行い, 肥育成績および飼料コストに及ぼす影響を 検討した。

\section{材料および方法}

県内地域未利用資源として, 県内食品工場加ら 排出される豆腐粕，大麦焼酎粕および整枝により 刈り捨てされる秋芽茶を供試した。

試験は, 市販試料 $200 \mathrm{~kg}$ に対し生豆腐粕 100 $\mathrm{kg}$ および焼酎廃液 $40 \mathrm{~kg}$ を混合して開始時水分 を $40 \%$ 程度に調整した後, 市販の飼料乾燥機に おいて攪挥乾燥処理（加熱乾燥 3 時間, 余熱乾燥 2 時間）を行った。

また，秋芽茶については，混合試料に外付けで 添加を行うため, 別途に攪拌乾燥処理を行った (加熱乾燥 1 時間, 余熱乾燥 1 時間)。

乾燥処理した飼料を利用した肥育試験につい て，供試豚は三元交雑種（LWD）去勢豚を用い て, コンクリート平床豚房で 6 頭群飼により行 い, 試験豚の平均体重が $30 \mathrm{~kg}$ を超えた時点で試 験を開始した。試験期間中は不断給餌とし, 肥育 前期から後期への飼料の切り替えは, 各試験区の 平均体重が 65 75 kg の範囲に達した段階で行 い, 供試豚が $110 \mathrm{~kg}$ に達した時点でと畜後, 枝肉 調査および肉質分析を行った。試験は, 市販飼料 のみを給与する対照区と乾燥処理をした飼料を給 与する試験区の 2 区を設置し, 試験区には乾燥し た秋芽茶を外付けで前期飼料に $2 \%$, 後期飼料に
$1 \%$ 添加給与した。

なお，試験区は乾燥処理した秋芽茶を肥育前期 に $2 \%$, 肥育後期に $1 \%$ の割合で外付け給与した。 調查項目として, 試験に供試した市販飼料およ び地域未利用資源の水分, 粗蛋白質などの一般成 分㧍よびリジンについて分析を行った。また，秋 芽茶についてはカテキン類の分析についても併せ て行った。供試飼料中のリジン含量はアミノ酸自 動分析法により測定し, カテキン含量は, 堀江と 木幡（2002a）および堀江ら（2002b）の方法によ り抽出を行い, 安田 (隈本) ら（2000）および Kumamoto ら (2000) の方法により HPLC で分析 した。その他の一般成分は常法（畜産試験場加工 第 2 研究室 1990）に準じた。

肥育豚への給与試験において, 発育成績につい ては飼料摂取量, 日増体量および肥育期間中の飼 料コストを, 枝肉成績については枝肉重量, 背脂 肪厚, 胸最長筋断面積等をそれぞれ調査した。胸 最長筋断面積は体長の $1 / 2$ の部位を超音波測定装 置（富士平社製，スーパーアイミート）でと畜前 日に測定した。

肥育期間中の試験区における飼料コストについ て, 市販飼料の購入コストに加えて一部代替した 地域未利用資源の運搬, 乾燥処理に係る諸経費 （運搬費, 燃料費, 電気代および人件費)を加算し て算出した。運搬費用は, 運搬距離を往復 100 $\mathrm{km} /$ 回とし, 燃料費は乾燥処理に係る燃料として の灯油代, 電気代を計上した。また, 人件費は 800 円/時として運搬, 乾燥に要した総時間を乗じて 算出した。試験期間中の地域未利用資源の運搬, 乾燥処理回数は 7 回実施した。

肉質成績について，と体から採取した第 4-13 胸椎間の胸最長筋のサンプルを採取し, 胸最長筋 の水分, 粗蛋白質含量, 筋内粗脂肪含量, 保水力, 伸展率, 肉色および脂肪色などの理化学性状の測 定を行った。また, 同背脂肪内層の脂肪融点を測 定した。一般理化学性状の測定は, 常法 (畜産試 験場加工第 2 研究室 1990）に準じた。

\section{結果}

表 1 に供試した豆腐粕および大麦焼酎粕成分を 示す。豆腐粕および大麦焼酎粕の乾物当たりの粗 
表 1. 供試した豆腐粕および大麦焼酎粕成分

Table 1. Chemical composition of soybean curd residue and shochu distiller's residue (Barley)

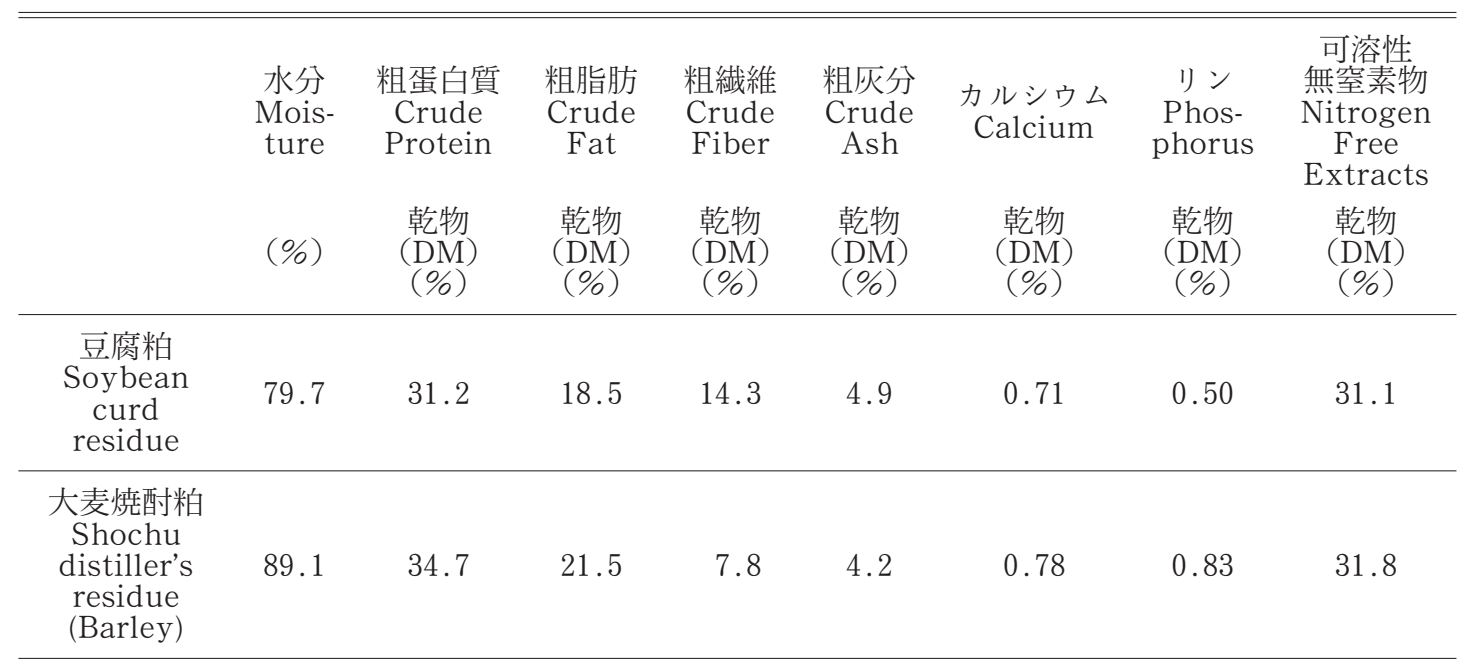

1) DM : 乾物（Dry Matter）

表 2. 供試した市販飼料成分

Table 2. Chemical composition of commercial diet

\begin{tabular}{|c|c|c|c|c|c|c|c|c|}
\hline & $\begin{array}{l}\text { 水分 } \\
\text { Mois- } \\
\text { ture }\end{array}$ & $\begin{array}{c}\text { 粗蛋白質 } \\
\text { Crude } \\
\text { Protein }\end{array}$ & $\begin{array}{c}\text { 粗脂肪 } \\
\text { Crude } \\
\text { Fat }\end{array}$ & $\begin{array}{l}\text { 粗繊維 } \\
\text { Crude } \\
\text { Fiber }\end{array}$ & $\begin{array}{l}\text { 粗灰分 } \\
\text { Crude } \\
\text { Ash }\end{array}$ & $\begin{array}{c}\text { カルシウム } \\
\text { Calcium }\end{array}$ & $\begin{array}{c}\text { リン } \\
\text { Phos- } \\
\text { phorus }\end{array}$ & $\begin{array}{c}\text { 可溶性 } \\
\text { 無室素物 } \\
\text { Nitrogen } \\
\text { Free } \\
\text { Extracts }\end{array}$ \\
\hline & $(\%)$ & $\begin{array}{l}\text { 乾物 } \\
(\mathrm{DM}) \\
(\%)\end{array}$ & $\begin{array}{l}\text { 乾物 } \\
(\mathrm{DM}) \\
(\%)\end{array}$ & $\begin{array}{l}\text { 乾物 } \\
(\mathrm{DM}) \\
(\%)\end{array}$ & $\begin{array}{l}\text { 乾物 } \\
(\mathrm{DM}) \\
(\%)\end{array}$ & $\begin{array}{l}\text { 乾物 } \\
(\mathrm{DM}) \\
(\%)\end{array}$ & $\begin{array}{l}\text { 乾物 } \\
(\mathrm{DM}) \\
(\%)\end{array}$ & $\begin{array}{c}\text { 乾物 } \\
\text { (DM) } \\
(\%)\end{array}$ \\
\hline $\begin{array}{c}\text { 肥育前期 } \\
\text { The first } \\
\text { fattening } \\
\text { diet }\end{array}$ & 15.0 & 17.9 & 3.3 & 3.4 & 4.9 & 0.64 & 0.49 & 70.5 \\
\hline $\begin{array}{c}\text { 肥育後期 } \\
\text { The second } \\
\text { fattening } \\
\text { diet }\end{array}$ & 17.0 & 18.2 & 4.2 & 3.1 & 4.6 & 0.61 & 0.45 & 69.9 \\
\hline
\end{tabular}

1) DM : 乾物 (Dry Matter)

蛋白質含量および粗脂肪含量は市販飼料と比べて $10 \%$ 以上高く飼料価值は高いものの, 水分含量が 80〜 90\% と高く推移した。

表 2 に供試した市販飼料成分および表 3 に供試 した市販飼料原料配合割合を示す。肥育後期飼料
は肥育前期飼料と比較して粗蛋白質含量を高く調 整しており，原料配合割合についても，トウモロ コシの一部を大麦および小麦等の穀類で代替して いる。

表 4 に市販飼料, 豆腐粕および大麦焼酎粕を混 
表 3. 供試した市販飼料原料配合割合

Table 3. Composition of commercial diet

\begin{tabular}{|c|c|c|}
\hline $\begin{array}{c}\text { 原料 } \\
\text { Materials }\end{array}$ & $\begin{array}{c}\text { 肥育前期 } \\
\text { The first fattening diet } \\
(\% \mathrm{FM})\end{array}$ & $\begin{array}{c}\text { 肥育後期 } \\
\text { The second fatting diet } \\
\text { (\% } \% \text { FM) }\end{array}$ \\
\hline $\begin{array}{c}\text { トウモロコシ } \\
\text { Corn }\end{array}$ & 56.1 & 47.2 \\
\hline $\begin{array}{c}\text { 大豆粕 } \\
\text { Soybean meal }\end{array}$ & 14.6 & 19.6 \\
\hline $\begin{array}{l}\text { グレインソルガム } \\
\text { Grain Sorghum }\end{array}$ & 15.0 & 20.0 \\
\hline $\begin{array}{c}\text { 大麦 } \\
\text { Barley }\end{array}$ & - & 5.0 \\
\hline $\begin{array}{c}\text { 小麦 } \\
\text { Wheat }\end{array}$ & - & 3.2 \\
\hline $\begin{array}{c}\text { フスマ } \\
\text { Wheat bran }\end{array}$ & 2.4 & 2.0 \\
\hline $\begin{array}{c}\text { ナタネ粕 } \\
\text { Rapeseed meal }\end{array}$ & 10.0 & - \\
\hline $\begin{array}{l}\text { ビタミン類等 } \\
\text { Vitamin et. al }\end{array}$ & 1.9 & 3.0 \\
\hline
\end{tabular}

1) $\mathrm{FM}:$ 原物（Fresh Matter）

表 4. 市販飼料, 豆腐粕拉よび大麦焼酎粕を混合した飼料の乾燥処理における成分変化

Table 4. Chemical composition change in the dry processing of complete diet of commercial diet, soybean curd and barley distiller's residue

\begin{tabular}{|c|c|c|c|c|c|c|c|c|c|}
\hline & & $\begin{array}{c}\text { 水分 } \\
\text { Mois- } \\
\text { ture } \\
(\%)\end{array}$ & $\begin{array}{c}\text { 粗蛋白質 } \\
\text { Crude } \\
\text { Protein } \\
\text { 乾物 } \\
(\mathrm{DM}) \\
(\%)\end{array}$ & $\begin{array}{c}\text { 粗脂肪 } \\
\text { Crude } \\
\text { Fat } \\
\\
\text { 乾物 } \\
(\mathrm{DM}) \\
(\%)\end{array}$ & $\begin{array}{l}\text { 粗繊維 } \\
\text { Crude } \\
\text { Fiber } \\
\\
\text { 乾物 } \\
(\mathrm{DM}) \\
(\%)\end{array}$ & $\begin{array}{c}\text { 粗灰分 } \\
\text { Crude } \\
\text { Ash } \\
\\
\text { 乾物 } \\
\text { (DM) } \\
(\%)\end{array}$ & $\begin{array}{c}\text { カル } \\
\text { シウム } \\
\text { Calcium } \\
\\
\text { 乾物 } \\
(\mathrm{DM}) \\
(\%)\end{array}$ & $\begin{array}{c}\text { リン } \\
\text { Phos- } \\
\text { phorus } \\
\text { 乾物 } \\
(\mathrm{DM}) \\
(\%)\end{array}$ & $\begin{array}{c}\text { 可溶性 } \\
\text { 無窒素物 } \\
\text { Nitrogen } \\
\text { Free } \\
\text { Extracts } \\
\text { 乾物 } \\
\text { (DM) } \\
(\%)\end{array}$ \\
\hline \multirow{2}{*}{$\begin{array}{c}\text { 肥育前期 } \\
\text { The first } \\
\text { fattening } \\
\text { diet }\end{array}$} & $\begin{array}{l}\text { 乾燥前 } \\
\text { Fresh } \\
\text { matter }\end{array}$ & 41.7 & 18.9 & 7.2 & 3.4 & 4.5 & 0.64 & 0.54 & 66.0 \\
\hline & $\begin{array}{c}\text { 乾燥後 } \\
\text { Dry } \\
\text { processing }\end{array}$ & 16.6 & 18.9 & 5.7 & 3.5 & 4.4 & 0.43 & 0.51 & 67.4 \\
\hline \multirow{2}{*}{$\begin{array}{c}\text { 肥育後期 } \\
\text { The second } \\
\text { fattening } \\
\text { diet }\end{array}$} & $\begin{array}{l}\text { 乾燥前 } \\
\text { Fresh } \\
\text { matter }\end{array}$ & 43.0 & 19.9 & 6.0 & 3.7 & 4.7 & 0.59 & 0.52 & 65.7 \\
\hline & $\begin{array}{c}\text { 乾燥後 } \\
\text { Dry } \\
\text { processing }\end{array}$ & 17.5 & 18.4 & 5.6 & 3.7 & 4.4 & 0.57 & 0.47 & 67.9 \\
\hline
\end{tabular}

1) DM : 乾物 (Dry Matter) 
表 5 . 供試茶葉（秋芽茶）の乾燥処理後の成分変化

Table 5. Chemical composition change in the dry processing of Autumn bud tea

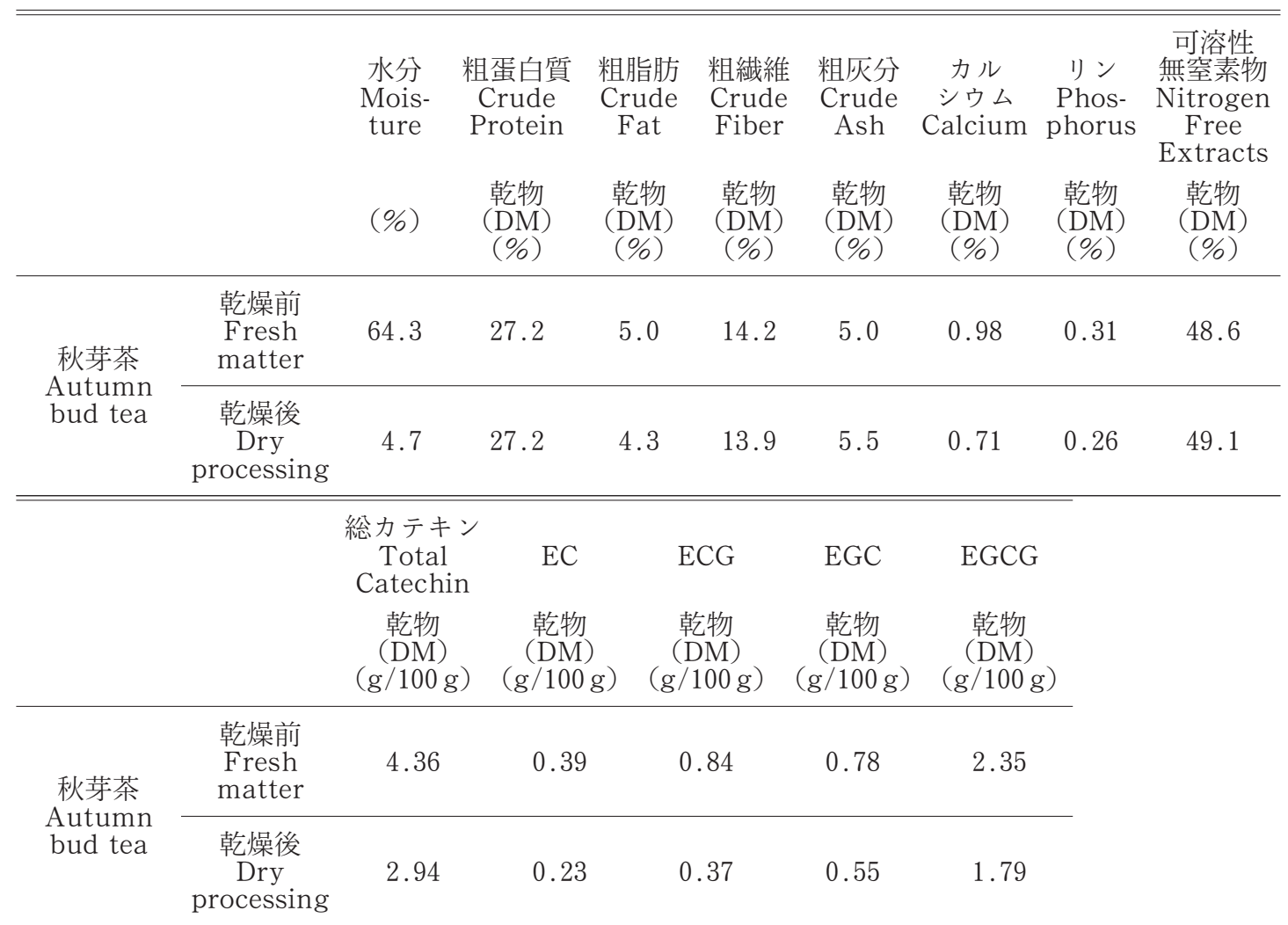

1) EC:エピカテキン (epicatechin), ECG: エピカテキンガレート (epicatechin gallate), EGC : エピガロカテキン (epigallocatechin), EGCG：エピガロカテキンガレート (epigallocatechin gallate)

2) DM : Dry Matter (乾物)

合した飼料の乾燥処理における成分変化を示す。

飼料乾燥処理を実施することにより, 水分を 16.6〜 17.5\% まで減少することができた。また， 他の項目について, 肥育前期飼料においては乾燥 後の粗脂肪含量は減少したが，顕著な变化は確認 されなかった。

表 5 に供試茶葉（秋芽茶）の乾燥処理後の成分 変化を示す。

秋芽茶は子葉と茎部分のみであるため， 2 時間 程度の乾燥処理で水分を $5 \%$ 以下に減少すること ができた。また, 乾燥処理後の成分変化について, 終了時の粗脂肪の減少が確認された。

表 6 に試験区に供試した飼料の成分，表 7 に試
験区に供試した飼料の乾物当たり配合割合を示 す。

乾物当たりの飼料の配合割合について，地域未 利用資源である豆腐粕, 大麦焼酎粕および製茶加 工残さにおける市販飼料への代替率は, 肥育前期 および肥育後期とともに約 15\% となった。

また, 試験期間中における加熱攪找乾燥処理 は，試験に供した肥育豚の採食量に応じて，1～2 週間に 1 回の割合で乾燥処理を実施しており，そ の期間でのカビ等の発生は確認されなかった。

表 8 に各試験区における日増体量, 飼料摂取量 および飼料コストを示す。

試験期間中の飼料摂取量は対照区が多くなった 
表 6. 試験区に供試した飼料の成分

Table 6. Chemical composition of experimental diet

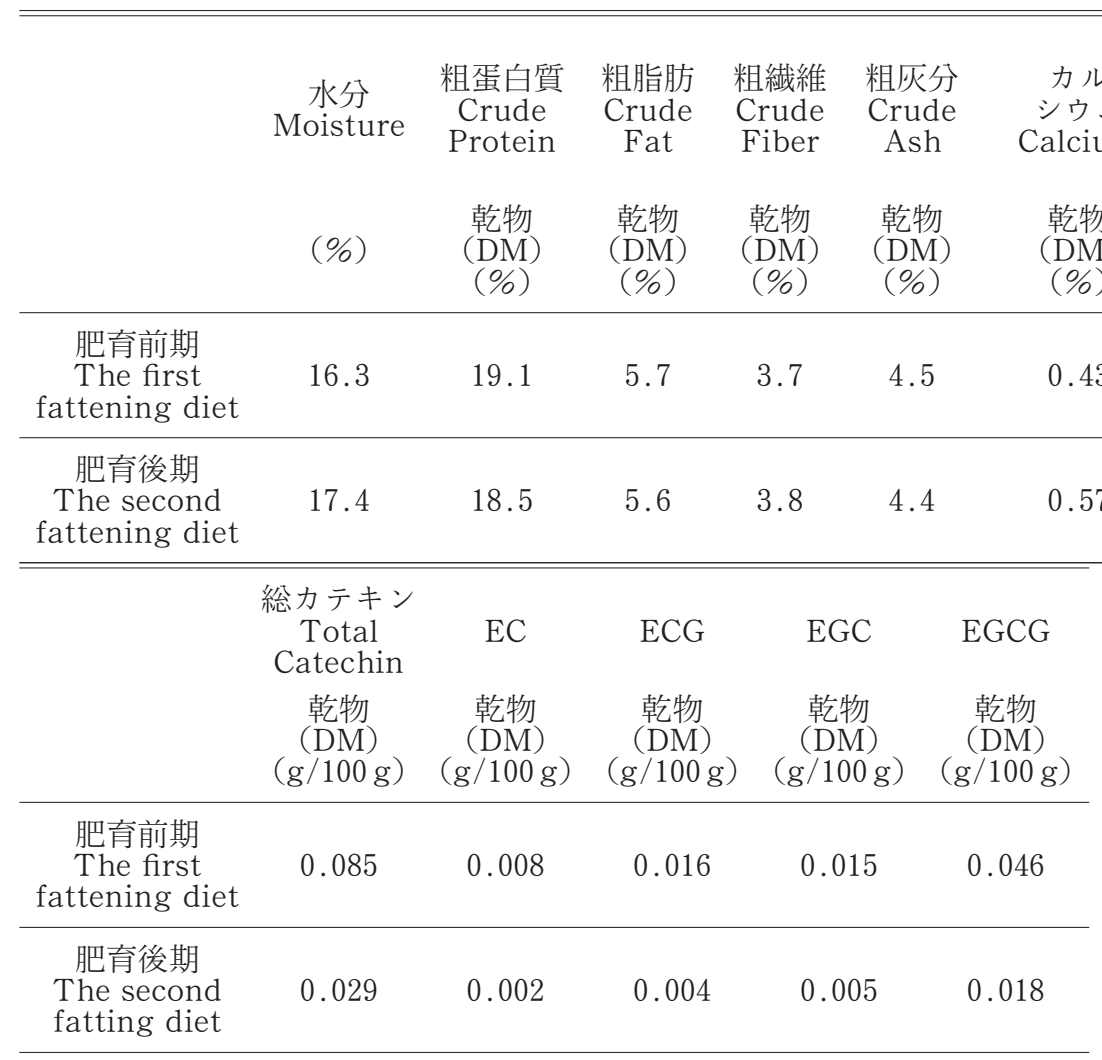

1) DM : 乾物 (Dry Matter)

表 7. 試験区に供試した飼料の乾物当たり配合割合

Table 7. Ingredient of experimental diet (DM)

\begin{tabular}{|c|c|c|}
\hline $\begin{array}{c}\text { 原料 } \\
\text { Materials }\end{array}$ & $\begin{array}{c}\text { 肥育前期 } \\
\text { The first } \\
\text { fattening diet } \\
(\% \mathrm{DM})\end{array}$ & $\begin{array}{l}\text { 肥育後期 } \\
\text { The second } \\
\text { fattening diet } \\
\text { (\%DM) }\end{array}$ \\
\hline $\begin{array}{c}\text { 市販飼料 } \\
\text { commercial diet }\end{array}$ & 85.4 & 86.1 \\
\hline $\begin{array}{l}\text { 豆腐粕 } \\
\text { Soybean curd residue }\end{array}$ & 10.2 & 10.5 \\
\hline $\begin{array}{c}\text { 大麦焼酎粕 } \\
\text { Shochu distiller's residue (Barley) }\end{array}$ & 2.2 & 2.3 \\
\hline $\begin{array}{c}\text { 秋芽茶 } \\
\text { Autumn bud tea }\end{array}$ & 2.2 & 1.1 \\
\hline
\end{tabular}

1) DM : 乾物 (Dry Matter) 
表 8 . 各試験区における日増体量, 飼料摂取量

Table 8. Daily gain, feed intake and feed cost

\begin{tabular}{|c|c|c|c|}
\hline & & $\begin{array}{l}\text { 対照区 } \\
\text { Control } \\
(n=6)\end{array}$ & $\begin{array}{c}\text { 試験区 } \\
\text { Experimental diet } \\
(n=6)\end{array}$ \\
\hline \multirow{3}{*}{$\begin{array}{c}\text { 飼料摂取量 }(\mathrm{kg} / \text { 頭・日 }) \\
\text { Feed intake }(\mathrm{kg} / \mathrm{one} \cdot \mathrm{day}) \\
{\left[\begin{array}{c}\text { リ ジン摂取量 }(\mathrm{g} / \text { 頭・日 }) \\
\text { Lysin intake }(\mathrm{g} / \text { one } \cdot \text { day })\end{array}\right]}\end{array}$} & $\begin{array}{c}\text { 全肥育期間 } \\
\text { All fattening period }\end{array}$ & $2.91 〔 23.57 〕$ & $2.76\lceil 21.90 〕$ \\
\hline & $\begin{array}{c}\text { 肥育前期 } \\
\text { The first fattening period }\end{array}$ & $2.58\lceil 20.85]$ & $2.82\lceil 22.98 〕$ \\
\hline & $\begin{array}{c}\text { 肥育後期 } \\
\text { The second fattening period }\end{array}$ & $3.11 〔 26.29 〕$ & $2.75 〔 20.82 〕$ \\
\hline \multirow{3}{*}{$\begin{array}{c}\text { 日増体量 }(\mathrm{kg} / \text { 頭・日 }) \\
\text { Daily gain }(\mathrm{kg} / \text { one·day })\end{array}$} & $\begin{array}{c}\text { 全肥育期間 } \\
\text { All fattening period }\end{array}$ & $0.92 \pm 0.07$ & $0.91 \pm 0.07$ \\
\hline & $\begin{array}{c}\text { 肥育前期 } \\
\text { The first fattening period }\end{array}$ & $0.77 \pm 0.08$ & $0.81 \pm 0.09$ \\
\hline & $\begin{array}{c}\text { 肥育後期 } \\
\text { The second fattening period }\end{array}$ & $1.07 \pm 0.09$ & $1.03 \pm 0.17$ \\
\hline \multicolumn{2}{|c|}{$\begin{array}{c}\text { 飼料要求率 } \\
\text { Feed Conversion Rate }\end{array}$} & 3.16 & 3.05 \\
\hline \multicolumn{2}{|c|}{$\begin{array}{c}\text { 肥育期間中飼料コスト（円/頭） } \\
\text { Feed cost of fattening period (yen/one) }\end{array}$} & 14,550 & 17,529 \\
\hline
\end{tabular}

1）試験区の飼料コスト

$=$ 市販飼料コスト $\times$ 市販飼料代替率 (乾物換算 $15 \%)+$ 乾燥コスト (燃料費 + 電気代 + 輸送費 + 人件費)

Feed cost of exmination period

$=$ cotrol feed cost $\times$ substitute rate of commericial diet (dry matter production conversion $15 \%)+$ dry processing cost (fuel cost + electricity cost + transportation cost + Personnel cost)

2) 日増体量 : 平均值士標準偏差

Daily gain : Means \pm Standard deviation

が，日増体量において試験区間に差は確認されな かった。また，全試験期間および肥育段階におけ るリジン摂取量は試験区が低くなったが，肥育豚 のリジン供給量 $17.3 \mathrm{~g} /$ 日 (独立行政法人農業・生 物特定産業技術研究機構編 2005) は満たしてい た。試験区の飼料要求率は対照区と比較して試験 区が低く, さらに, 地域未利用資源を乾物換算で $15 \%$ 代替利用したが，肥育期間中の肥育豚 1 頭当 たりの飼料コストは試験区が対照区と比較して約 3,000 円程度高くなった。

表 9 に各試験区における枝肉成績の比較を示 す。枝肉歩留は対照区と比べて試験区が有意に小 さくなった $(\mathrm{P}>0.05)$ が, 枝肉重量, ロース芯面
積等においては有意な差は確認されなかった。ま た背脂肪厚において, 茶葉を添加した試験区が対 照区と比較して薄い傾向にあった。

表 10 に各試験区における肉質成績およびロー ス断面の比較を示す。

肉色の赤色度（a 值）について試験区は対照区 と比較して有意に低くなったが, 胸最長筋中の粗 脂肪含量が高くなったことが原因として考えられ た。対照区と比較して試験区の飼料中の粗脂肪含 量は高かったが, 脂肪融点には有意差はなく, 地 域未利用資源を肥育豚に給与する場合に最も問題 となる軟脂の発生は確認されなかった。 
表 9. 各試験区における枝肉成績の比較

Table 9. Effect of carcass measurements

\begin{tabular}{|c|c|c|}
\hline & $\begin{array}{l}\text { 対照区 } \\
\text { Control } \\
(n=6)\end{array}$ & $\begin{array}{c}\text { 試験区 } \\
\text { Experimental diet } \\
(n=6)\end{array}$ \\
\hline $\begin{array}{l}\text { 枝肉重量 }(\mathrm{kg}) \\
\text { Carcass weight }\end{array}$ & $78.4 \pm 4.9$ & $74.3 \pm 4.5$ \\
\hline $\begin{array}{l}\text { 枝肉歩留 (\%) } \\
\text { Carcass yield }\end{array}$ & $67.1 \pm 1.5^{\mathrm{a}}$ & $63.8 \pm 0.7^{\mathrm{b}}$ \\
\hline $\begin{array}{c}\text { 屠体長 }(\mathrm{cm}) \\
\text { Carcass length }\end{array}$ & $100.4 \pm 2.5$ & $99.3 \pm 1.0$ \\
\hline $\begin{array}{c}\text { 背腰長 I （cm） } \\
\text { Back loinlength ( I ) }\end{array}$ & $84.8 \pm 2.5$ & $82.5 \pm 2.9$ \\
\hline $\begin{array}{c}\text { 背腰長 } I \text { ( }(\mathrm{cm}) \\
\text { Back loinlength }(\text { II })\end{array}$ & $73.6 \pm 0.5$ & $71.3 \pm 2.3$ \\
\hline $\begin{array}{c}\text { 屠体幅 }(\mathrm{cm}) \\
\text { Carcass width }\end{array}$ & $36.6 \pm 1.1$ & $35.3 \pm 1.0$ \\
\hline $\begin{array}{c}\text { 背脂肪厚 (肩) (cm) } \\
\text { Backfat depth (shoulder) }\end{array}$ & $4.0 \pm 0.6$ & $3.7 \pm 0.3$ \\
\hline $\begin{array}{l}\text { 背脂肪厚 (背) (cm) } \\
\text { Backfat depth (back) }\end{array}$ & $2.7 \pm 0.4$ & $2.1 \pm 0.5$ \\
\hline $\begin{array}{l}\text { 背脂肪厚 (腰) }(\mathrm{cm}) \\
\text { Backfat depth (loin) }\end{array}$ & $4.1 \pm 1.0$ & $3.6 \pm 0.5$ \\
\hline $\begin{array}{l}\text { ロース断面積 }\left(\mathrm{cm}^{2}\right) \\
\text { Loin area }\end{array}$ & $31.6 \pm 1.7$ & $32.9 \pm 0.7$ \\
\hline
\end{tabular}

1）平均值士標準偏差，異符号間で有意差 $(\mathrm{p}<0.05)$

Means \pm Standard deviation, Shows significant difference $(\mathrm{P}<0.05)$

\section{考察}

佐賀県内に扔いて安定した供給が可能な地域未 利用資源として豆腐粕および大麦焼酎粕を肥育豚 への飼料利用を検討するために，市販飼料と混合 して乾燥処理した飼料による肥育豚への給与試験 を行った。

県内地域未利用資源の成分について，豆腐粕お よび大麦焼酎粕は乾物当たりの粗蛋白質含量およ び粗脂肪含量は市販飼料と比べて高いものの，水 分が 80 90\% 程度の高水分であるため飼料とし て利用するためには早急な品質保持対策が必要と なる。本試験においては, 水分含量が高い地域未 利用資源を効率的に乾燥処理するために，低水分 の市販飼料と混合して飼料乾燥機を利用した加熱 攪拌乾燥処理を実施することで，水分を16.6 $17.5 \%$ まで減少することができ，試験期間中の力
ビ等の発生が確認さなかったため, 品質保全性を 改善するには有効な方法であると考えられた。

試験期間中の飼料要求率について試験区は対照 区と比較して低くなった。

飼料要求率が試験区において低くなった理由と して, 供試飼料中の粗蛋白質含量, 粗脂肪含量等 の栄養成分が対照区と比較して試験区において高 くなったことで効率的に肥育されたことが考えら れるが，試験区に添加した大麦焼酎粕中には，ク エン酸， $\alpha$-トコフェロール，ポリフェノール等が 含まれ成長促進効果が高いことが林ら（2009）に よって報告されており，大麦焼酎粕に含有する機 能性成分の効果について屯併せて検討する必要が ある。

また，肥育期間中の肥育豚 1 頭当たりの飼料コ ストは試験区が対照区と比較して約 3,000 円程度 高くなったが, 運搬や乾燥に係る燃料, 電気代と 
表 10. 各試験区における肉質成績およびロース断面の比較

Table 10. Effect of meat quality and loin section

\begin{tabular}{|c|c|c|}
\hline & $\begin{array}{l}\text { 対照区 } \\
\text { Control } \\
(n=6)\end{array}$ & $\begin{array}{c}\text { 試験区 } \\
\text { Experimental diet } \\
(\mathrm{n}=6)\end{array}$ \\
\hline Moisture $(\%)$ & $72.2 \pm 0.8$ & $71.7 \pm 1.3$ \\
\hline $\begin{array}{c}\text { 保水力（加圧濾過法） } \\
\text { Water preservation } \\
{\left[\begin{array}{c}\text { Pressurization filter } \\
\text { paper method }\end{array}\right]}\end{array}$ & $65.8 \pm 6.2$ & $64.8 \pm 5.3$ \\
\hline $\begin{array}{c}\text { 進展率 } \\
\text { Extension rate（\%) }\end{array}$ & $26.2 \pm 2.4$ & $24.1 \pm 2.2$ \\
\hline $\begin{array}{c}\text { 脂肪融点 } \\
\text { Fat melting temperature }\left({ }^{\circ} \mathrm{C}\right)\end{array}$ & $35.4 \pm 2.7$ & $34.5 \pm 1.8$ \\
\hline $\begin{array}{c}\text { 粗蛋白質（原物\%) } \\
\text { Crude protein (FM\%) }\end{array}$ & $21.8 \pm 1.2$ & $21.9 \pm 0.5$ \\
\hline $\begin{array}{l}\text { 粗脂肪（原物\%） } \\
\text { Crude fat (FM\%) }\end{array}$ & $4.6 \pm 1.0$ & $5.5 \pm 1.2$ \\
\hline $\begin{array}{l}\text { 肉色 } \\
\text { Meat } \\
\text { color }\end{array}\left\{\begin{array}{l}\mathrm{L} \text { (明度)（bright） } \\
\mathrm{a} \text { (赤色度)（red） } \\
\mathrm{b} \text { (黄色度) (yellow) }\end{array}\right.$ & $\begin{array}{c}49.2 \pm 2.1 \\
6.6 \pm 0.5^{\mathrm{a}} \\
2.0 \pm 0.5\end{array}$ & $\begin{array}{c}49.4 \pm 2.8 \\
5.5 \pm 0.7^{\mathrm{b}} \\
1.5 \pm 0.7\end{array}$ \\
\hline 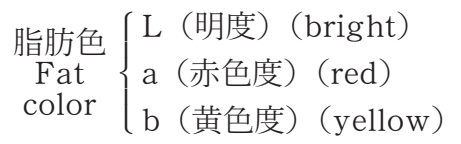 & $\begin{array}{r}73.7 \pm 1.6 \\
3.1 \pm 0.9 \\
4.4 \pm 0.7\end{array}$ & $\begin{array}{r}72.8 \pm 0.9 \\
3.3 \pm 0.7 \\
3.4 \pm 0.7\end{array}$ \\
\hline
\end{tabular}

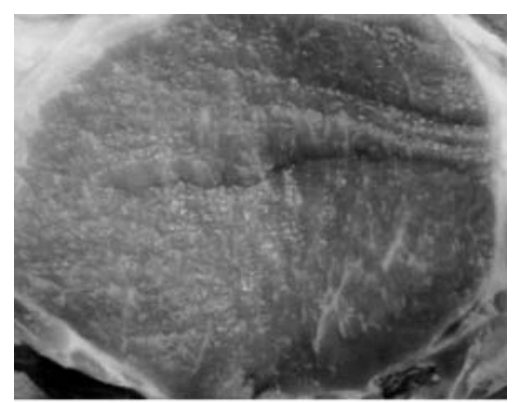

Control(対照区)

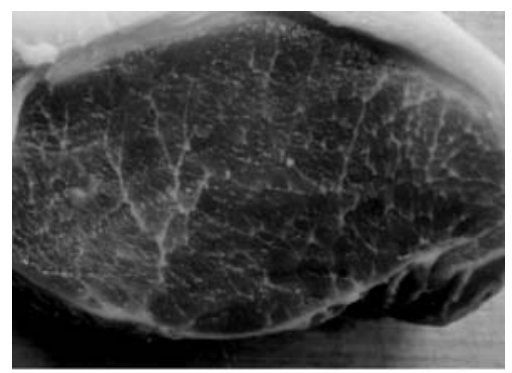

Experimental diet(試験区)

1）平均值士標準偏差，異符号間で有意差 $(\mathrm{p}<0.05)$

Means \pm Standard deviation, Shows significant difference $(\mathrm{P}<0.05)$

併せて人件費が肥育豚 1 頭当たり 17,000 円程度 要したことが理由として考えられる。さらに，乾 燥処理における水分調整剂として市販飼料と直接 混合したことで給与頭数が制限され，運搬回数を 増加させる要因となったため，水分調整としてふ すま等の単味飼料と混合して乾燥処理を実施し て，給与する際に市販飼料と攪拌混合することで 乾燥処理量が低減され，母豚 100 頭一貫経営にお いて試算した場合，対照区と比較して肥育豚 1 頭 当たりの飼料コストが約 3,000 円程度安価になる ため，コスト低減に適用した乾燥処理技術を確立 する必要がある。

肉質成績について，試験区は対照区と比較して ロース中の粗脂肪含量が高くなった。飼料中リジ
ン含量を低下させることで豚の筋内脂肪含量が増 加させる傾向があるとしている（岩元ら 2005 ; 家 入ら 2007）が，本試験に供試した飼料中のリジン 含量は肥育豚のリジン供給量 $17.3 \mathrm{~g} /$ 日 (独立行政 法人農業・生物特定産業技術研究機構編 2005）を 満たしており，リジン不足によるロース中の粗脂 肪含量の増加が原因とは考えにくいため, 加熱乾 燥時の蛋白変性等原因についても併せて追及する 必要がある。また，試験区における歩留りの低下 は脂肪付着量が関係しているものと思われた。

枝肉形質においては，飼料のエネルギー水準が 高まると背脂肪が厚くなる傾向にあることを松本 ら（2008）は確認している。茶を添加することで, 飼料中の粗繊維含量の増加により飼料摂取量が減 
少し, さらにカテキン含量の増加により脂肪代謝 が促進され体脂肪が低減することが確認されてい る（茶山 2003 ; 村瀬と時光 2004）。しかし, 脇屋 ら（2009）は製茶残さの添加割合を肥育前期に市 販飼料の重量に対し $2 \%$, 肥育後期に $1 \%$ に添加 することで, 飼料摂取量および増体に影響を及ぼ すことなく, 添加による背脂肪厚の低減効果を脇 屋らは確認しており, 本試験においても試験区間 において飼料摂取量に有意な差はなかったことよ り, 茶葉中のカテキン類の代謝促進効果により背 脂肪厚が低減されたことが考えられる。

本試験に供試した秋芽茶のカテキン類含量につ いて, 製茶加工残さにおいては乾物当たり 16〜 19 g/100 g の含有量があることが脇屋ら（2009）に よって報告されているが, $4.4 \mathrm{~g} / 100 \mathrm{~g}$ と低く, さ らに乾燥処理に伴い減少が確認されたため, 刏取 適期や乾燥時間等の調整が必要となることが推察 された。

地域未利用資源を給与する際の課題点として, 豚肉中の不飽和脂肪酸の増加に伴う脂肪融点の低 下（軟脂）が問題となり, 軟脂発生に大きく関与 するのは飼料中の脂肪含量および脂肪酸組成の影 響が大きいとされている（独立行政法人農業・生 物特定産業技術研究機構編 2005)。また, 地域未 利用資源を給与する際に懸念される脂肪融点の低 下（軟脂）の対応策として, 大本ら（1984）は, 飼料中の粗脂肪含量が $10 \%$ の場合概ね軟脂が発 生するが，粗脂肪含量を $7 \%$ に抑えると，脂肪の 硬度やしまりが向上するとしている。さらに, 丹 羽ら（1994）は市販飼料と大麦添加飼料とを比較 した場合, 大麦添加区の方が脂肪中の飽和脂肪酸 含量が高くなることを確認している。本試験にお いて, 試験区での胸最長筋で軟脂の発生は確認さ れなかった理由として, 試験区における粗脂肪含 量が 5.6〜 5.7\% と低かったこと，および地域未利 用資源として大麦焼酎粕を利用したこと等が考え られるが，軟脂を抑制する焼酎廃液の添加量と併 せて茶成分中のカテキン添加による抑制効果につ いても検討する必要がある。

これまで, 焼酎粕や豆腐粕等の水分含量が高い 地域未利用資源は, 保存性が悪く, 乾燥処理に莫 大な費用を要するために全量廃棄物処理されてい
た。それを本研究の方法で, 飼料乾燥機を利用し て市販飼料等を利用した効率的な乾燥技術および 飼料給与体系を確立することで，水分含量が高い 地域未利用資源の有効利用が図れるとともに, 飼 料の自給率向上にもつながる。また, 地域未利用 資源を製造する県内業者においても，会社や販売 製品のイメージアップによる収益向上につながる と考えられる。

今後は，飼料製造コストを相殺するために他の 豚肉と差別化してブランド化を目指して, 飼料中 の必須アミノ酸およびビタミン，ミネラル等微量 成分を考慮した調製技術や給与技術を確立する。

\section{文献}

茶山和敏. 2003. お茶で肥満を防止する。緑茶通 信, $7: 15-22$. 世界緑茶協会. 静岡.

畜産試験場加工第 2 研究室 : 1990, 豚肉の品質改 善に関する研究実施要領, 14-21, 農林水産省畜 産試験場, 茨城。

独立行政法人農業 - 生物特定産業技術研究機構編 : 2005, 「養分要求量に影響する要因と飼養上注 意すべき事項」, 日本飼養標準・豚（2005 年度 版), 34-74, 中央畜産会, 東京.

林 國興 - 前田真希 - 北原和弥 - 田子山徹 - 大塚 彰: 2009 , 焼酎粕上清濃縮液給与によるブロイ ラーの生産性および肉質の改善, 日畜会報, 80, 35-39.

堀之内正次郎 - 三角久志 - 岩切正芳 - 尾花尚明 · 神坂明茂 - 入江正和 - 高橋俊浩 - 森田哲夫 - 林 國興 : 2008 , 肥育豚に対する乾燥焼酎粕給与試 験（第 1 報），宮崎畜試研報， 21，57-61.

石田昌弘・赤尾友雪・高橋照美 - 條々和実 - 宇田 和男: 2007 , ブドウ粕を利用した豚の肉質改善 技術（第 1 報），山梨畜研報告， 53，10-16.

家入誠二・崎村武司・石橋 誠 - 勝俣昌也 - 梶 雄次 : 2007 , 肥育豚へのパン屑利用低リジン飼 料給与による筋内脂肪含量の増加, 日豚会誌 $44,8-16$.

入江正和 : 2002, 豚肉質の評価法, 日豚会誌， 39, 221-254.

岩元英治・設楽 治・入江正和 : 2005, パン添加 飼料給与が豚の増体量および肉質に及ぼす影 響. 日畜会報, 76, 15-22.

小平貴都子 - 入江正和 - 堀之内正次郎 - 岩切正 芳 $\cdot$ 竹之山愼一 - 六車三治男 $\cdot$ 高橋俊浩 $\cdot$ 森田 哲夫・松葉賢次 甲斐敬康 : 2007 , ワイン粕給 
与が肥育豚の発育と枝肉・肉質特性に及ぼす影 響, 日豚会誌，44，127-135.

堀江秀樹・木幡勝則 : 2002a, 茶の機能一生体機 能の新たな可能性一, 395-402, 村松敬一郎・小 國伊太郎・伊勢村護・杉山公男・山本（前田） 万里編, 学会出版センター, 東京.

堀江秀樹・山本万里・ 氏原ともみ : $2002 b$ 茶葉中 カテキン類分析のための抽出方法の検討, 茶業 研究報告, 94, 60-64.

Kumamoto M, Sonoda T, Takedomi K, Tabata $M: 2000$, Enhanced separation and elution of catechins in HPLC using mixed-solvents of waters, acetonitrile and ethyl acetate as the mobile phase. Analytical Sciences, 16, 139144.

松本友紀子 - 鈴木邦夫 - 高橋圭二 ・岡崎好子 : 2008，コンビニエンスストアに由来するエコ フィード給与が肥育後期の豚の発育と肉質に及 ぼす影響，千葉畜セ研報，8，11-15.

村瀬孝利・時光一郎. 2004. 茶カテキンの機能.
香料 (香りの本). $223: 117-125$.

丹羽太左衛門. 1994. 養豚ハンドブック.529533. 養賢堂. 東京.

農林水産省大臣官房統計情報部：2008, 平成 19 年度食品循環資源の再利用等実態調査.

大本邦介・入江正和・黄 准建 - 顧 振華. 1984. 乾燥残飯の消化率. 大阪府農林技術セン 夕一研究報告, $21: 67-70$.

坂井隆宏・安田みどり・武富和美・大曲秀明・河 原弘文・宮崎秀雄・式町秀明 : 2007 , 製茶加工 残さ給与が肥育豚の枝肉および肉質に与える効 果，西日本畜産学会報，50，63-69.

脇屋裕一郎・安田みどり・坂井隆宏・大曲秀明・ 河原弘文・宮崎秀雄・下平秀丸 : 2009, 二番茶 製茶加工残さ給与が肥育豚の枝肉および肉質に 与える効果, 日本暖地畜産学会報，52，51-56.

安田 (隈本) みどり・尊田民喜・加治屋勝子・田 端正明 : 2000, HPLC-電気化学検出器を用いた 緑茶中のカテキンの高感度分析, 永原学園・西 九州大学・佐賀短期大学紀要, 30, 9-14. 